\title{
The Effects of Cash Conversion Cycle on Profitability: An Insight into the Agriculture and Food Industries in Thailand
}

\author{
Nguyen Thi Phuong Linh* and Sundaresan Mohanlingam
}

\begin{abstract}
Manuscript type: Research paper.

Research aims: This study investigates the relationship between cash conversion cycle and profitability that exists in the agriculture and food industries in Thailand. It specifically aims to examine the influence of production cycle, cash collection cycle, and cash payment cycle on profitability. In addition, it also aims to measure the influence of control variables such as size and debt ratios have on profitability.

Design/ Methodology/ Approach: This study analysed the data of 34 listed companies in agriculture and food industry in the Stock Exchange of Thailand from 2009 to 2013. Pearson's correlation and the regression analysis approach were used to examine the relationship between cash conversion cycle and profitability.

Research findings: The results indicate that cash conversion cycle (CCC) has a significant inverse relationship with profitability in the agriculture and food companies in Thailand. Further, production cycle and debt ratio were found to have a significant negative relationship with return on assets (ROA) while payment cycle and size have a positive relationship with return on equity (ROE). No significant relationship was found between cash collection cycle and profitability.

Theoretical contributions/ Originality: This study expands on the theoretical concepts of cash conversion cycle and its effects on profitability. Although studies have been done on manufacturing
\end{abstract}

\footnotetext{
* Corresponding author: Nguyen Thi Phuong Linh is an Instructor at the Faculty of Business, Asia-Pacific International University, Thailand. Email: linh@apiu.edu

Sundaresan Mohanlingam is a Lecturer at the Faculty of Business, Asia-Pacific International University, Thailand. Email: sundaresan@apiu.edu
} 
firms and industrial SMEs, no study has focused on the agriculture and food industries in Thailand.

Practitioner/ Policy implications: Insights gained from the findings can be used to improve working capital decisions and to provide policy directions in the management of agriculture and food industries in Thailand. This study is especially significant as it deals with perishable goods where time is of vital importance for the inventory, collection and payment cycle management since these factors have subsequent influence on firm profitability.

Research limitation: This study is limited to 34 listed firms in Thailand and for a period of five years due to the limited access to the annual reports of firms. In addition, some annual reports were only available in the Thai language which hindered the interpretation of data for the current study. Therefore, future studies should investigate the agriculture and food industries of other ASEAN countries by studying the same relationship for comparison.

Keywords: Cash Conversion Cycle, Production Cycle, Cash Collection Cycle, Payment Cycle, Profitability, Working Capital Management.

JEL Classification: M41, L25, Z12

\section{Introduction}

Robust financial health is vital for every organisation, not only for it to thrive but also to survive. Performance, risk and market value of firms have always been influenced by decisions involving working capital by finance managers. The link between liquidity and profitability is insightful. It is assumed that when the firm has higher liquidity, it has lower risks and lesser profitability (Bolek, 2013). One of the measurements used by organisations to assess how well a firm manages its liquidity and working capital is its cash conversion cycle (CCC).

Cash conversion cycle is determined from the time taken to purchase raw materials, through manufacturing until collecting money from sale of goods on account (Besly, 2000). The CCC is measured by deducting the payment deferral period made to suppliers from the total of inventory conversion period and receivables collection period (Yucel \& Kurt, 2002). Payment deferral period (payment cycle) is the time a firm takes for raw materials to be ordered, received and paid for. Inventory conversion period (production cycle) is the time it takes to manufacture and sell its inventory. Receivables collection period (cash collection cycle) is the length of time a firm needs to collect the money 
from its credit sales. Firms can lessen their cash conversion cycles to boost profitability. This can be done by reducing the receivables collection period, decreasing the inventory conversion period, and lengthening the payment period (Panigrahi, 2013). Since businesses are particularly interested in looking for ways to continue and to increase their financial performance, it is important for them to closely monitor their CCC.

Much research has been done in the area of liquidity, working capital, cash conversion cycle, firm size, and their influence on profitability but there has been no conclusive evidence showing the negative or positive relationship between CCC and profitability. A few studies (Kaur \& Singh, 2016; Panigrahi, 2013) have reported the positive relationship whereas others (Oseifuah \& Gyekye, 2016; Anser \& Malik, 2013; Majeed, Makki, Saleem, \& Aziz, 2013; Murugesu, 2013; Attari \& Raza, 2012) have reported on the negative relationship showing the inconsistency. To some extent, some studies (Hemalatha \& Kamalavalli, 2017; Ikechukwu \& Nwakaego, 2016; Bolek, 2013; Wongthatsanekorn, 2010) have even reported that there are no relationship between CCC and profitability. Most of these studies on the relationship between CCC and profitability have been done based on general firms or manufacturing companies, small and medium enterprises, or in some cases selected listed companies in stock exchanges. There is limited work done on the relationship between CCC and profitability of the agriculture and food sector of Thailand.

Data show that by mid twenty-first century, a minimum of 70 per cent increase in agricultural production will be needed to satisfy the world's hunger even as climate change, soil erosion and urbanisation will diminish arable land (Deutsche Gesellschaft für Internationale Zusammenarbeit (GIZ), July 2011). Agribusiness has been influential in increasing exports, and at the same time triggering development of high end yield in national markets. Thailand's agricultural and food industries have been an interesting mix of economic prosperity (resulting in billions of baht a year) and as well as upholding the Thai agrarian culture. Thailand is known as the "Kitchen of the World" largely due to its natural wealth which has been enriched by technology, food safety research and development, and conforming to high quality global standards. Thailand is the leader in food export in Asia and is also one of the biggest producers of food products like rice, tuna, frozen seafood, chicken and canned pineapples (Thailand Board of Investment, 2013). Agricultural productions have increased the Thai GDP by about 
8.3 per cent in 2016 (World Bank, 2016). More than half of the food produced in Thailand is exported to other countries, making it one of the leading producers and exporters of processed food products in the world. Statistics show that Thailand exported USD24 billion of food in 2016 and was the largest food exporter in ASEAN and the 12th leading food exporter in the world (Arunmas, 2017).

The study of cash conversion cycle is particularly significant for agriculture and food industries. Unlike other businesses, the agriculture and food industries have some unique risk factors to consider. Besides the general risks (access to growth capital, competition, etc.), the specific risks associated with the agricultural businesses (biological and weather related risks, commodity price volatility, infrastructure in rural areas and government polices) can greatly influence the profitability of this sector. In addition, the special nature of the supply chain and logistics design for food industries can amplify the challenges such companies face in working capital management. More importantly, speed plays a crucial role in this industry. Responsiveness is a key factor which influences speed; and the food industry in particular is an example of this "off-the-shelf" responsiveness characteristic (Kritchanchai, 2004). If a country cannot stock its produced food for a longer period of time, the possibilities of exporting such foods become limited to fresh foods only which are associated with higher costs (Afzal, Lawrey, Anaholy, \& Gope, 2018). In other words, the agriculture and food industries are distinctive in the sense that the produce of these industries have a very limited shelf life.

The study also assumes significance because of the unique nature of the agriculture and food industries which deals with perishable commodities. In addition, inventory management is a crucial factor which influences CCC and profitability. The authors have chosen Thailand as their area of study as it is among the highest producers of food products in the world as well as the largest sole net food exporter in ASEAN (Arunmas, 2017).

The primary purpose of the study is to measure the role of cash conversion cycle in explaining the variations in profitability of agriculture and food companies in Thailand. This study also attempts to measure the influence of each of the following: production cycle, cash collection cycle, and cash payment cycle on the profitability of the agriculture and food industries in Thailand. Finally, this study also examines the influence selected proxies of control/moderating variables (size and debt ratio) have on the relationship between CCC and profitability. 
The rest of this paper is preceded by Section 2 which reviews the relevant literature leading to the hypotheses development. Section 3 provides a description of the methodology. Section 4 presents and discusses the results of the empirical analysis and Section 5 concludes the study.

\section{Literature Review and Hypotheses Development}

Studies looking at the relationship between liquidity/working capital and profitability have attracted considerable attention, especially in the field of short-term financial management (Bolek, 2013). In fact, there has been a growing concentration among researchers on this area in the last 20 years (Attari \& Raza, 2012). Studies by Deloof (2003) and Yucel and Kurt (2002) stated that the profitability of a business is greatly influenced by the administration of its working capital.

Among the many ways to measure working capital, cash conversion cycle (CCC) has been acknowledged to be a dynamic indicator of working capital management. This is verified by Ebbens and Johnson (2013) who observed that working capital management is more frequently measured by CCC. Literature (Gitman, 1982) has shown that CCC is a more accurate ratio than conventional indicators such as the current ratio. The concept of CCC was initiated by Richards and Laughlin (1980) who recommended it as a strong measure to examine how effectively a company manages its working capital (Attari \& Raza, 2012). Gentry, Vaidyanathan, \& Wai (1990) confirmed that the value of a business is commonly related to CCC.

A number of studies have established the relationship between CCC and profitability. Earlier works on the impact of working capital management on profitability can be traced to particular lines of businesses like buildings, services, natural resources, energy, logistics or production industries. Studying 60,000 American firms in seven industries over 20 years, Shin and Soenen (1998) used net trade cycle as a proxy for liquidity when analysing the correlation between working capital management and profitability. They found a strong negative relationship. They mentioned that shorter net trade cycles could bring higher stock returns. A similar study by Reheman and Nasr (2007) at Karachi Stock Exchange reported the same negative relationship when studying 94 Pakistani firms over a period of six years. Another study (Majeed et al., 2013) observed the effects of different factors on profitability and determined that the average receivables period, 
production period, and CCC were negatively associated with firm's performance. The same authors suggested that the possible reasons for this negative relationship could be longer holding period of inventory, delay in collection of receivables, and quick payment of debts resulting in higher CCC and lower profitability.

In another empirical study on the relationship between CCC, cash management and profitability, it is found that the CCC is positively related to liquidity ratios and negatively related to return on asset (ROA) and return on equity (ROE) (Yucel \& Kurt, 2002). Similar results are found by Murugesu (2013). Studying 100 companies in the Bombay Stock Exchange, Chatterjee (2012) reports a significant negative relationship between the elements of working capital management and firm's performance. In a more recent study, Oseifuah and Gyekye (2016) confirmed the negative relationship between working capital management and profitability. The same study also reported a negative relationship between inventory conversion and receivables collection with profitability and positive relationship between accounts payable deferral period and profitability. Their findings implied that managers could increase profits by reducing the duration of production and cash collection and by increasing the time period for payables. GrosseRuyken, Wagner and Jonke (2011), likewise, also reported a significant negative relationship between CCC and return on capital employed (ROCE). They argued that the optimal level of CCC for responsive supply chain must be evaluated holistically. They then concluded that the right working capital management is determined by the type of business, supply chain design, and risk factors within the supply chain. The authors also proposed that changes in all components of the CCC must be monitored so as to achieve a balanced CCC. This can reduce the total outstanding working capital.

In contrast to the above studies, research also shows conflicting results. Kaur and Singh (2016) reported a positive relationship between profitability as measured by return on assets (ROA) and return on equity (ROE) and accounts receivables days, accounts payable days and cash conversion cycle. Grosse-Ruyken, Wagner and Jonke (2011) found a negative relationship between CCC and return on capital employed for all industries but Panigrahi (2013) reported contrasting results. Panigrahi (2013) investigated cement manufacturing companies in India and found that CCC had a strong positive relationship with return on assets (ROA) and return on equity (ROE). This positive relationship is due to the fact that the firm collects money on receivables before it pays 
to the suppliers. The finding suggests that the relationship between CCC and profitability may vary due to the nature of the different industries. This also means that it is not mandatory for CCC to be lowered in order to ensure higher profitability. In a study of the Athens Stock Exchange, Lyroudi and Lazaridis (2000) focussed on the association between liquidity, profitability and leverage ratios of 82 firms in the food industry. They concluded that a positive relationship exists between CCC and return on assets (ROA). Similar findings were reported by Sharma (2011) who analysed 263 non-financial firms in India over an eight year period and by Gill, Nahum and Mathur (2010) who inspected 88 American production firms from 2005 to 2007. Nonetheless, Ikechukwu and Nwakaego (2016) reported that CCC has no significant effect on firm's profitability. In a ten year study of tyre companies in India, Hemalatha and Kamalavalli (2017) concluded that CCC has no significant association with ROE and ROA.

Although many studies have reported the correlations between CCC and profitability, the results have been mixed and non-conclusive. In view of these inconsistent findings, it is crucial to test the relationship between CCC and profitability to see if it is positive, negative or neutral, especially for specific industries. In theory, if firms can sell their inventories, collect money from customers quickly, and delay paying their suppliers, it will save costs and as a result increase the profits (Brigham \& Houston, 2013). As such, the following hypothesis is proposed:

$\mathrm{H}_{1}$ : Cash conversion cycle has a significant inverse relationship with profitability.

Among the various factors that contribute towards the computation of CCC, it has been noted that not all factors have the same relationships towards profitability. Ikechukwu and Nwakaego (2016) stated that inventory turnover ratio and credit turnover ratio have significant and positive effect on firms' profitability. In contrast, Hemalatha and Kamalavalli (2017) concluded that inventory turnover ratio has no significant association with ROE and ROA. Similarly, Wongthatsanekorn (2010) reported no relationship between inventory conversion period and assets turnover, and negative relationships between receivable conversion period, payable deferral period and assets turnover. In contrast, in a similar study of agriculture and food industries in Saudi Arabia, Husain and Alnefaee (2016) found a high negative correlation between payment cycle and gross operating 
profit, but a weak positive relationship between collection period and profitability, and moderate negative correlation between inventory turnover and gross profits. Due to these inconsistent findings, the current study proposes the following hypotheses:

$\mathrm{H}_{2}$ : Production cycle has a significant relationship with profitability.

$\mathrm{H}_{3}$ : Cash collection cycle has a significant relationship with profitability.

$\mathrm{H}_{4}$ : Cash payment cycle has a significant relationship with profitability.

\section{Research Methodology}

\subsection{Data and Sampling}

The population for this research study includes all the agriculture and food companies listed in Thailand. Secondary data (annual reports for five years from 2009 to 2013) were collected from the listed agriculture and food companies' websites in Thailand. According to the availability of data, the annual reports of a total of 34 listed firms were extracted from the 45 agricultural and food companies listed on the Stock Exchange of Thailand.

Upon collection of the secondary data, quantitative methods were used to perform the statistical analysis. The statistical tools include Descriptive Statistics, Pearson's Correlation, and Regression Analysis.

\subsection{Research Models and Variable Definitions}

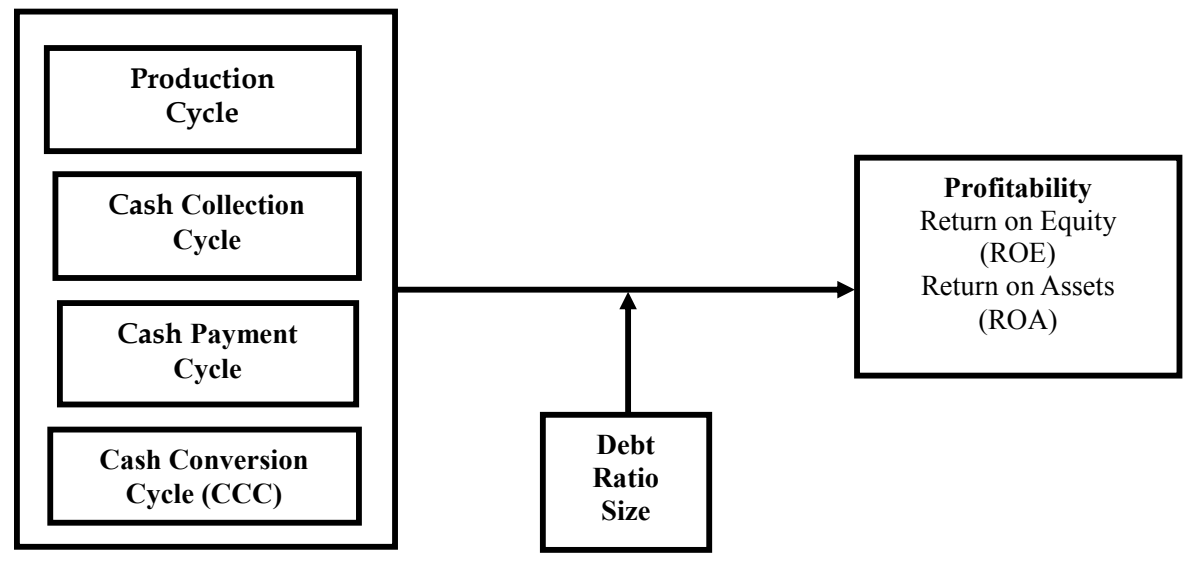

Figure 1: The Effects of CCC and its Components on Profitability

Source: Adapted from Wongthatsanekorn (2010) and Shah and Chaudhry (2013). 
The conceptual framework suggests that CCC can influence the bottom line of businesses. In this model, CCC is projected as the independent variable and profitability is projected as the dependent variable. Since CCC is determined by the production cycle, collection cycle and payment cycle, it is only fair to assume and probe if each of these factors may also affect firm's profitability. In this regard, CCC is measured by deducting the payment deferral period made to suppliers from the total of the inventory conversion period and the receivables collection period (Brigham \& Houston, 2013).

Profitability is measured by return on equity (ROE) and return on assets (ROA) (Gibson, 2011). Although both ratios are used to assess a company's performance, they do not represent the same thing (McClure, 2014). While ROE indicates how a company effectively generates earnings from the investments of its stockholders, the ROA shows how much profits a company earns for each dollar of its assets. According to McClure (2014), the main difference between ROE and ROA is the financial leverage or debt. If a company does not borrow money, ROE will be the same as ROA. When a company takes on financial leverage, ROE will be higher than ROA. McClure (2014) stated that using both ROE and ROA to assess financial performance and company effectiveness is better. The inclusion of both as proxies of profitability in this study offers a more complete assessment.

In addition, the company's characteristics such as size and debt ratio can also significantly affect firm profitability. Chatterjee (2012) and Majeed et al. (2013) reported a positive relationship between size and profitability while Panigrahi (2013) and Anser and Malik (2013) indicated no link between them. Separate studies (Yucel \& Kurt, 2002; Raheman \& Nasr, 2007; Bolek, 2013) looking at the relationship between debt ratio and profitability also showed mixed results. While Yucel and Kurt (2002), Raheman and Nasr (2007) and Bolek (2013) highlighted the negative relationship, Panigrahi (2013) and Anser and Malik (2013) maintained that there is no relationship between debt ratio and profitability.

Given these observations, the current study will focus on examining the relationship and influence of these independent variables (CCC, production cycle, collection cycle and payment cycle) as well as the moderating variables (size and debt ratio) on the dependent variables (ROE \& ROA). The current study will use the following measures as defined in Table 1. 
Nguyen Thi Phuong Linh and Sundaresan Mohanlingam

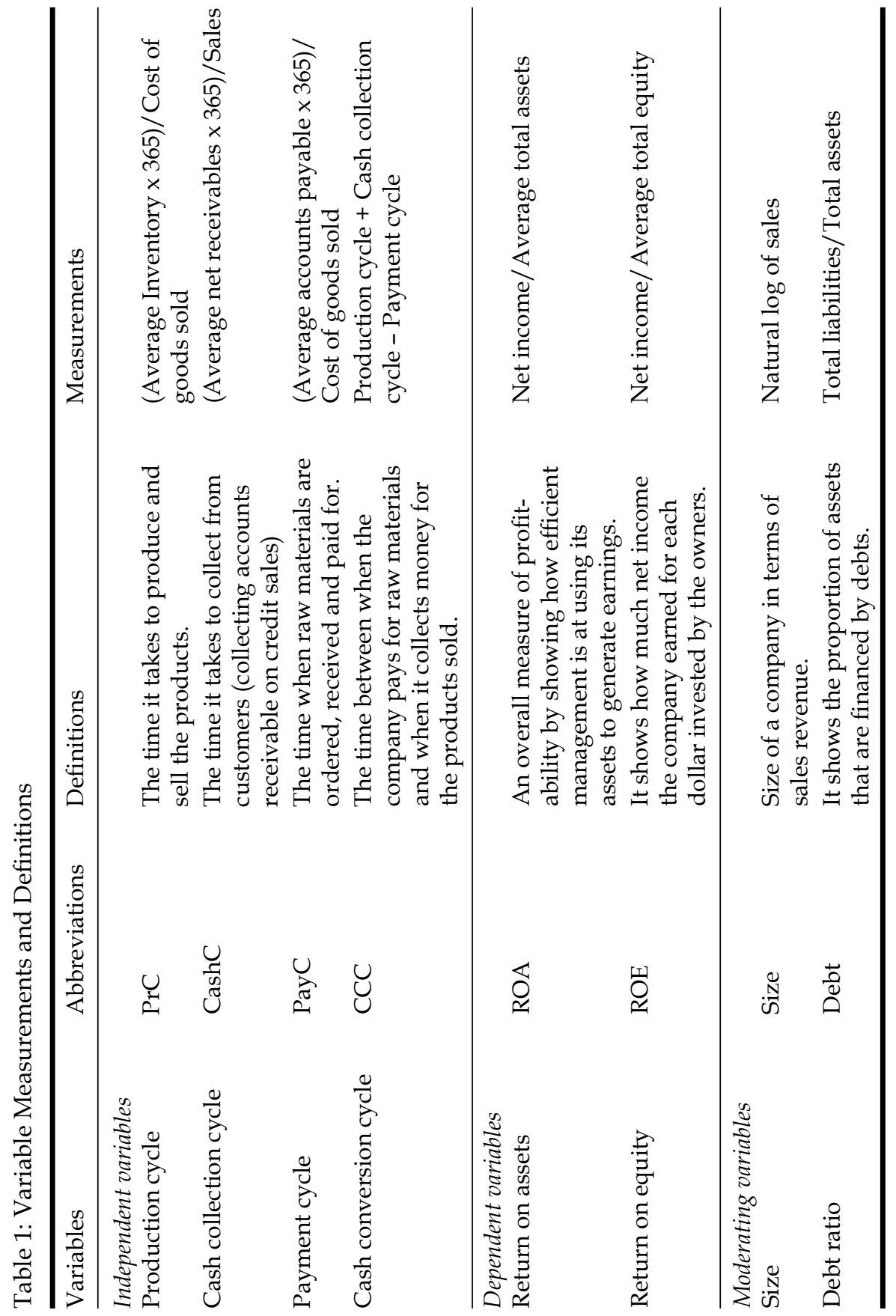


To understand the relationship between cash conversion cycle (CCC) and profitability, this study examines the following models:

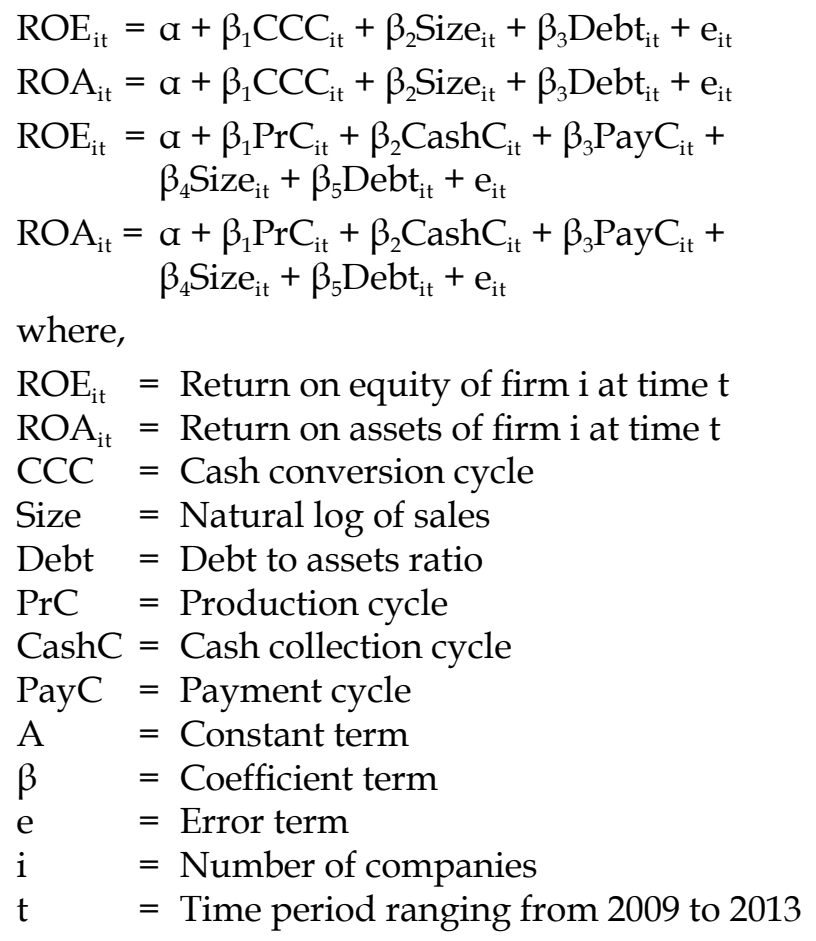

where,

$\mathrm{ROE}_{\text {it }}=$ Return on equity of firm i at timet

CCC = Cash conversion cycle

Size $=$ Natural $\log$ of sales

Debt $=$ Debt to assets ratio

PrC = Production cycle

CashC $=$ Cash collection cycle

PayC = Payment cycle

$\mathrm{A}=$ Constant term

$\beta=$ Coefficient term

$\mathrm{e}=$ Error term

$=$ Number of companies

$t$ - $=$ Time period ranging from 2009 to 2013

\section{Findings}

\subsection{Descriptive Statistics}

The descriptive statistics extracted from 34 agriculture and food companies for the period of 2009 to 2013, provided a total of 170 observations as tabulated in Table 2 . The mean value of production cycle is 58.8 days, indicating that agriculture and food companies in Thailand took 59 days to produce, store and sell the inventory. The standard deviation was 41.92 days. The mean value of cash collection cycle is 34.5 which shows that these companies spent 34.5 days to collect cash from their credit sales (standard deviation is 17.38 days). In addition, payment cycle has a mean value of 34.9 days which is the period that these companies need to pay off their suppliers. The median for production cycle, cash collection cycle and payment cycle are 52.88, 33.24 and 27.47 respectively which shows the centre of the data for 
Table 2: Descriptive Statistics

\begin{tabular}{lrrrrr}
\hline Variables & Minimum & Maximum & Mean & Median & $\begin{array}{c}\text { Std. } \\
\text { Deviation }\end{array}$ \\
\hline PrC & 0.00 & 261.85 & 58.84 & 52.88 & 41.93 \\
CashC & 6.47 & 96.97 & 34.56 & 33.24 & 17.39 \\
PayC & 1.53 & 196.60 & 34.93 & 27.47 & 31.27 \\
CCC & -68.36 & 327.40 & 58.47 & 59.68 & 52.74 \\
Size & 19.06 & 26.69 & 22.36 & 22.15 & 1.27 \\
DebtRatio & 0.03 & 0.85 & 0.38 & 0.36 & 0.22 \\
ROE & -0.22 & 3.13 & 0.17 & 0.14 & 0.26 \\
ROA & -0.10 & 0.49 & 0.11 & 0.09 & 0.10 \\
\hline
\end{tabular}

Note: $\operatorname{PrC}=$ Production cycle, CashC $=$ Cash collection cycle, PayC $=$ Payment cycle, $\mathrm{CCC}=$ Cash Conversion Cycle, $\mathrm{ROE}=$ Return on Equity of firm, ROA $=$ Return on Assets of firm.

these variables. The cash conversion cycle has a mean of 58.47 which indicates that on an average, it took 58 days for the agriculture and food companies in Thailand to transform their inventory and other resource inputs into cash with the standard deviation of 17.38 days and median of 59.67 days. In a study of the same industry which was conducted by Hussain and Alnefaee (2016) in Saudi Arabia, the mean of production cycle, cash collection cycle, payment cycle and cash conversion cycle was $77.01,26.11,72.43$, and 30.99 days respectively. This implies that production cycle and payment cycle are shorter in Thailand than in Saudi Arabia while cash collection cycle and cash conversion cycle are longer in Thailand than in Saudi Arabia. In a similar study done in food industries in Greece, results showed that the mean of the production cycle, cash collection cycle, payment cycle and cash conversion cycle was reported as 96.95, 122.76, 192.58 and 28.33 days respectively (Lyroudi \& Larzridis, 2000). This means that all other variables except for cash conversion cycle are shorter in Thailand.

The findings from Table 2 show that the mean values of return on assets (ROA) is 11 per cent and return on equity (ROE) is 17 per cent with their standard deviations being 2.6 per cent and 1 per cent respectively. These numbers indicate that on an average, the agriculture and food companies in Thailand can generate 11 per cent and 17 per cent profits from their assets and equities. The total debts over total assets of these companies was noted to be 37.5 per cent on average. 


\subsection{Correlation Analysis}

To understand the relationship between the variables being studied, Pearson's correlation was applied. Table 3 confirms the relationship between production cycle, cash collection cycle, payment cycle and cash conversion cycle. The finding reports a strong positive relationship between production cycle, cash collection cycle and cash conversion cycle. It also observes a negative relationship between payment cycle and cash conversion cycle. It further confirms the theory indicating that shorter production cycle and cash collection cycle together with longer payment cycle can result in shorter cash conversion cycle (Brigham \& Houston, 2013).

The correlation results also indicate that cash conversion cycle has a significant inverse relationship with profitability (return on equity and return on assets). These results confirm and accept $\mathrm{H}_{1}$. This effect means that the shorter the cash conversion time is, the higher the profits generated by the agriculture and food companies in Thailand. These findings are consistent with other empirical research results (Oseifuah \& Gyekye, 2016; Anser \& Malik, 2013; Majeed et al., 2013; Murugesu, 2013; Attari \& Raza, 2012).

Findings from Table 3 indicate that moderating variable size does not have any significant relationship with cash conversion cycle or profitability. This is also confirmed by previous studies (Panigrahi, 2013; Anser \& Malik, 2013). However, results from Table 3 (Pearson correlation) indicate that the moderating variable debt ratio has a

Table 3: Pearson Correlations

\begin{tabular}{lcccccccc}
\hline & PrC & CashC & PayC & CCC & Size & DebtRatio & ROE & ROA \\
\hline PrC & 1 & & & & & & & \\
CashC & .092 & 1 & & & & & & \\
PayC & .046 & $.246^{* *}$ & 1 & & & & & \\
CCC & $.798^{* *}$ & $.256^{* *}$ & $-.475^{* *}$ & 1 & & & & \\
Size & -.146 & -.129 & -.086 & -.108 & 1 & & & \\
DebtRatio & -.031 & .139 & $.305^{* *}$ & $-.160^{*}$ & $.446^{* *}$ & 1 & & \\
ROE & -.048 & .035 & $.418^{* *}$ & $-.275^{* *}$ & -.005 & .087 & 1 & \\
ROA & $-.203^{* *}$ & -.078 & .067 & $-.227^{* *}$ & -.087 & $-.443^{* *}$ & $.340^{* *}$ & 1 \\
\hline
\end{tabular}

Note: $\operatorname{PrC}=$ Production cycle, CashC $=$ Cash collection cycle, PayC $=$ Payment cycle, $\mathrm{CCC}=$ Cash Conversion Cycle, $\mathrm{ROE}=$ Return on Equity of firm, ROA $=$ Return on Assets of firm, ** Correlation is significant at the 0.01 level (2-tailed), * Correlation is significant at the 0.05 level (2-tailed). 
significant negative relationship with return on assets (ROA) and cash conversion cycle. This outcome suggests that companies with high debt ratios have low profitability (ROA) but take shorter time to convert their input into cash. Research papers of Yucel \& Kurt (2002) and Bolek (2013) similarly reported the negative relationship between debt ratio and profitability. The findings demonstrate that the debt ratio has a positive relationship with payment cycle which means that when the debt ratio increases, companies take longer to pay their debts.

The results also demonstrate that production cycle has a negative relationship with return on assets (ROA). This means that when production cycle is short, the firms make higher profits. In fact, short production cycles can help the agriculture and food companies, where production speed and storage time are crucial to save costs and increase profits. Thus, $\mathrm{H}_{2}$ is accepted. This result supports the findings of Oseifuah and Gyekye (2016) and Deloof (2003) where a similar result of negative correlation was found between the number of days in inventory and gross operating profit. The results presented in Table 3 indicate that there is no significant relationship between cash collection period and ROE or ROA. As such, $\mathrm{H}_{3}$ is rejected.

The results also indicate that payment cycle has a significant positive relationship with return on equity (ROE) as shown by Pearson's correlation. This suggests that the longer the payment cycle, the higher the company's profitability. The longer these companies delay in paying their creditors, the more profits they can generate, (assuming that they use the money to invest elsewhere). Therefore, $\mathrm{H}_{4}$ is accepted. This finding also confirms the results of Oseifuah and Gyekye (2016), Kaur and Singh (2016) and Makori \& Jagongo (2013) who reported a significant positive relationship between payable period and return on assets. Nonetheless, this result also differs from many studies (Wongthatsanekorn, 2010; Deloof, 2003; Raheman \& Naser, 2007; Shah \& Chaudhry, 2013) where a negative relationship between payable period and profitability is reported. This may also point to the fact that agriculture and food industries in Thailand practice a deferred payment policy which increases their profitability.

\subsection{Regression Analysis}

The regression method was used to describe the nature of the relationship between the variables (production cycle, cash collection cycle, cash payment cycle, cash conversion cycle, debt ratio, size, and 
return on assets or equity) and to indicate whether they are positive or negative, linear or non-linear. More precisely, the analysis seeks to examine the four linear regression models (as listed earlier) and to study their implications. Time (year) dummy variables were also included to control the year effects and they were assigned a value of 1 for each of the following years: 2010, 2011, 2012 and 2013. Year 2009 was used as the comparison year and assigned a value equal to 0. YearDummy2, YearDummy3, YearDummy4, and YearDummy5 represent year 2010, 2011, 2012, and 2013 respectively. Table 4 illustrates the linear relationship between cash conversion cycle (CCC), debt ratio, size, and return on equity (ROE).

Table 4: Effects of Cash Conversion Cycle on Return on Equity

\begin{tabular}{|c|c|c|c|c|c|}
\hline \multirow{2}{*}{$\begin{array}{l}\text { Model } 1 \\
\text { DV: ROE }\end{array}$} & \multicolumn{2}{|c|}{ Unstandardised } & \multirow{2}{*}{$\begin{array}{c}\text { Standardised } \\
\text { Beta }(\beta)\end{array}$} & \multirow[t]{2}{*}{$\mathrm{T}$} & \multirow[t]{2}{*}{$\mathrm{p}$} \\
\hline & B & Std. Error & & & \\
\hline Constant & .560 & .290 & & 1.928 & .056 \\
\hline CCC & -.002 & .000 & -.315 & -4.293 & $.000^{* *}$ \\
\hline Size & -.012 & .014 & -.073 & -.846 & .399 \\
\hline DebtRatio & .136 & .100 & .117 & 1.351 & 179 \\
\hline YearDummy2 & -.101 & .059 & -.158 & -1.718 & .088 \\
\hline YearDummy3 & -.090 & .059 & -.141 & -1.532 & .127 \\
\hline YearDummy4 & -.085 & .059 & -.133 & -1.445 & .150 \\
\hline YearDummy5 & -.157 & .059 & -.245 & -2.667 & $.008^{* *}$ \\
\hline
\end{tabular}

$\mathrm{R}=0.384, \mathrm{R}^{2}=0.147$, Adjusted $\mathrm{R}^{2}=0.111, \mathrm{~F}=4.003^{* *}$

Note: $\mathrm{CCC}=$ Cash Conversion Cycle, $\mathrm{ROE}=$ Return on Equity of firm, ${ }^{* *}$ Significant at $1 \%$ level.

Linear regression for model 1 is suggested as:

$$
\begin{aligned}
\mathrm{ROE}_{\mathrm{it}}= & 0.56-0.002 \mathrm{CCC}_{\mathrm{it}}-0.012 \text { Size }_{\mathrm{it}}+0.136 \text { DebtRatio }_{i t}- \\
& 0.101 \text { YearDummy }-0.90 \text { YearDummy3 }- \\
& 0.085 \text { YearDummy }-0.157 \text { YearDummy }+\mathrm{e}_{\mathrm{it}}
\end{aligned}
$$

Table 4 shows that cash conversion cycle has a significant inverse relationship with return on equity $(p<0.01)$ while size and debt ratio do not show any significance. This outcome is consistent with the results of Anser and Malik (2013). The correlation $(R=38.4 \%)$ suggests a weak relationship between the independent and dependent variables. The 
coefficient of the determination $\left(\mathrm{R}^{2}=14.7 \%\right)$ means that 14.7 per cent of the variation in return on equity (ROE) can be attributed to cash conversion cycle, size and debt ratio.

According to the results presented in Tables 4 and 5, it can be seen that the coefficients for cash conversion cycle were noted to be significantly negative in relationship with return on equity (ROE) and return on assets (ROA). This result confirms the outcome of previous studies (Anser \& Malik, 2013; Yucel \& Kurt, 2002; Murugesu, 2013; Majeed et al., 2013). However, the moderate variable size has a significant positive relationship with return on assets while debt ratio has a negative relationship with ROA. This result also supports previous studies (Panigrahi, 2013) and (Raheman \& Nasr, 2007) where the coefficient size is related significantly positive to net operating profit. Likewise, Gill et al. (2010) also reported a significantly negative coefficient for debt ratio in relationship with operating profit. In Table 5 , the correlation ( $R=57.2 \%$ ) indicates a moderate relationship between the independent and dependent variables. The coefficient of the determination $\left(\mathrm{R}^{2}=32.7 \%\right)$ means that 32.7 per cent of the amount of variation in return on assets can be explained by cash conversion cycle, size and debt ratio. The other 67.3 per cent of the variation is a result of other factors.

Table 5: Effects of Cash Conversion Cycle on Return on Assets

\begin{tabular}{|c|c|c|c|c|c|}
\hline \multirow{2}{*}{$\begin{array}{l}\text { Model } 2 \\
\text { DV: ROA }\end{array}$} & \multicolumn{2}{|c|}{ Unstandardised } & \multirow{2}{*}{$\begin{array}{c}\text { Standardised } \\
\text { Beta }(\beta)\end{array}$} & \multirow[t]{2}{*}{$\mathrm{T}$} & \multirow[t]{2}{*}{$\mathrm{p}$} \\
\hline & B & Std. Error & & & \\
\hline Constant & -.072 & .098 & & -.728 & .468 \\
\hline $\mathrm{CCC}$ & -.001 & .000 & -.328 & -5.030 & $.000^{* *}$ \\
\hline Size & .014 & .005 & .228 & 2.990 & $.003^{* *}$ \\
\hline DebtRatio & -.251 & .034 & -.566 & -7.369 & $.000^{* *}$ \\
\hline YearDummy2 & -.007 & .020 & -.027 & -.333 & .739 \\
\hline YearDummy3 & .013 & .020 & .053 & .651 & .516 \\
\hline YearDummy4 & .015 & .020 & .063 & .773 & .441 \\
\hline YearDummy5 & -.022 & .020 & -.092 & -1.123 & .263 \\
\hline
\end{tabular}

Note $:$ CCC $=$ Cash Conversion Cycle, ROA $=$ Return on Assets of firm, ** Significant at $1 \%$ level. 
Linear regression for model 2 can be written as:

$$
\begin{aligned}
\mathrm{ROA}_{\mathrm{it}}= & -0.072-0.001 \mathrm{CCC}_{\mathrm{it}}+0.014 \text { Size }_{\mathrm{it}}-0.251 \text { DebtRatio }_{\mathrm{it}}- \\
& 0.007 \text { YearDummy }+0.013 \text { YearDummy3 }+ \\
& 0.015 \text { YearDummy }-0.022 \text { YearDummy }+\mathrm{e}_{\mathrm{it}}
\end{aligned}
$$

The regression analysis in Table 6 and Table 7 shows the strength of the relationship between production cycle, cash collection cycle, payment cycle and return on equity and return on assets.

\begin{tabular}{|c|c|c|c|c|c|}
\hline \multirow{2}{*}{$\begin{array}{l}\text { Model } 3 \\
\text { DV: ROE }\end{array}$} & \multicolumn{2}{|c|}{ Unstandardised } & \multirow{2}{*}{$\begin{array}{c}\text { Standardised } \\
\text { Beta }(\beta)\end{array}$} & \multirow[t]{2}{*}{$\mathrm{T}$} & \multirow[t]{2}{*}{$\mathrm{p}$} \\
\hline & B & Std. Error & & & \\
\hline Constant & .257 & .279 & & .922 & .358 \\
\hline $\operatorname{PrC}$ & .000 & .000 & -.057 & -.839 & .403 \\
\hline CashC & -.002 & .001 & -.131 & -1.831 & .069 \\
\hline PayC & .005 & .001 & .522 & 7.064 & $.000^{* *}$ \\
\hline Size & -.002 & .013 & -.014 & -.173 & .863 \\
\hline DebtRatio & -.012 & .099 & -.011 & -.126 & .900 \\
\hline YearDummy2 & -.103 & .054 & -.161 & -1.900 & .059 \\
\hline YearDummy3 & -.088 & .055 & -.137 & -1.607 & .110 \\
\hline YearDummy4 & -.093 & .055 & -.145 & -1.699 & .091 \\
\hline YearDummy5 & -.182 & .055 & -.285 & -3.333 & $.001^{* *}$ \\
\hline
\end{tabular}

Table 6: Effects of Production Cycle, Cash Collection Cycle and Payment Cycle on Return on Equity

$\mathrm{R}=0.529, \mathrm{R}^{2}=0.28$, Adjusted $\mathrm{R}^{2}=0.24, \mathrm{~F}=6.926^{* *}$

Note $: \operatorname{PrC}=$ Production cycle, CashC $=$ Cash collection cycle, PayC $=$ Payment cycle, ROE $=$ Return on Equity of firm, ${ }^{* *}$ Significant at $1 \%$ level.

Linear regression for model 3 is suggested as:

$$
\begin{aligned}
\mathrm{ROE}_{\mathrm{it}}= & 0.257+0.000 \mathrm{PrC}_{\mathrm{it}}-0.002 \mathrm{CashC}_{\mathrm{it}}+0.005 \mathrm{PayC}_{\mathrm{it}}- \\
& 0.002 \text { Size }_{\mathrm{it}}-0.012 \text { DebtRatio } \\
& 0.088 \text { YearDummy }_{\mathrm{it}}-0.093 \text { YearDearDummy }- \\
& \text { 0.182YearDummy5 + } \mathrm{e}_{\mathrm{it}}
\end{aligned}
$$

The outcomes indicate that payment cycle has a significant positive relationship with return on equity (ROE) while other variables (except yeardummy5) do not show any significance in model 3. Majeed et al. (2013) and Hassan, Imran, Amjad and Hussain (2014) also found a positive coefficient for payable period in the relationship with ROE 
although this is not significant. The correlation $(\mathrm{R}=52.9 \%)$ indicates a moderate relationship between the independent and dependent variables while the coefficient of the determination $\left(\mathrm{R}^{2}=28 \%\right)$ means that 28 per cent of the amount of variation in return on equity (ROE) can be attributed to the independent variables.

Table 7: Effects of Production Cycle, Cash Collection Cycle and Payment Cycle on Return on Assets

\begin{tabular}{|c|c|c|c|c|c|}
\hline \multirow{2}{*}{$\begin{array}{l}\text { Model } 4 \\
\text { DV: ROA }\end{array}$} & \multicolumn{2}{|c|}{ Unstandardised } & \multirow{2}{*}{$\begin{array}{c}\text { Standardised } \\
\text { Beta }(\beta)\end{array}$} & \multirow[t]{2}{*}{$\mathrm{T}$} & \multirow[t]{2}{*}{$\mathrm{p}$} \\
\hline & B & Std. Error & & & \\
\hline Constant & -.133 & .101 & & -1.315 & 190 \\
\hline $\operatorname{PrC}$ & -.001 & .000 & -.223 & -3.455 & $.001^{* *}$ \\
\hline CashC & .000 & .000 & -.036 & -.526 & .600 \\
\hline PayC & .001 & .000 & .297 & 4.224 & $.000^{\star *}$ \\
\hline Size & .016 & .005 & .258 & 3.362 & $.001^{* *}$ \\
\hline DebtRatio & -.278 & .036 & -.628 & -7.761 & $.000^{* *}$ \\
\hline YearDummy2 & -.006 & .020 & -.026 & -.321 & .749 \\
\hline YearDummy3 & .015 & .020 & .060 & .742 & .459 \\
\hline YearDummy4 & .016 & .020 & .066 & .815 & 416 \\
\hline YearDummy5 & -.025 & .020 & -.102 & -1.254 & .212 \\
\hline
\end{tabular}

$\mathrm{R}=0.59, \mathrm{R}^{2}=0.348$, Adjusted $\mathrm{R}^{2}=0.311, \mathrm{~F}=9.495^{* *}$

Note $:$ PrC $=$ Production cycle CashC $=$ Cash collection cycle, PayC $=$ Payment cycle, ROA $=$ Return on Assets of firm, ${ }^{* *}$ Significant at $1 \%$ level.

Linear regression for model 4 can be written as:

$$
\begin{aligned}
\mathrm{ROA}_{\mathrm{it}}= & -0.133-0.001 \mathrm{PrC}_{\mathrm{it}}+0.000 \text { CashC }_{\mathrm{it}}+0.001 \mathrm{PayC}_{\mathrm{it}}+ \\
& 0.016 \text { Size }_{\mathrm{it}}-0.278 \text { DebtRatio } \\
& 0.015 \text { YearDummy3 }_{\mathrm{it}}-0.006 \text { YearDummy }+ \\
& 0.025 \text { YearDummy }+\mathrm{e}_{\mathrm{it}}
\end{aligned}
$$

The results in Table 7 indicate that all other variables, except cash collection cycle, have significant relationship with return on assets (ROA). Payment cycle and size have a significant positive relationship with return on assets (ROA) while production cycle and debt ratio have a significant inverse relationship with return on assets (ROA). Similar coefficients for these variables are reported in the study of Iqbal and Zhuquan (2015) and Makori \& Jagongo (2013). The correlation ( $\mathrm{R}=$ $59 \%$ ) indicates a moderate relationship between the independent and 
dependent variables. The coefficient of the determination $\left(\mathrm{R}^{2}=34.8 \%\right)$ means that 34.8 per cent of variation in return on assets (ROA) can be explained by production cycle, cash collection cycle, payment cycle, size and debt ratio. The other 64.2 per cent of the variation is a result of other factors.

\section{Conclusion}

\subsection{Discussion and Implications}

This study has investigated the impact of cash conversion cycle on profitability in 34 listed agriculture and food companies in Thailand for a five year period lasting from 2009 to 2013. The results show that cash conversion cycle has a significant inverse relationship with the profitability of agriculture and food companies in Thailand. The results also confirm the earlier studies in this subject and contribute to the existing literature in the study of this relationship. The results of this study are especially crucial to policy makers, industry managers and practitioners in the agriculture and food industries in Thailand as they deal with perishable goods and face unique challenges in logistics and supply chain management. This study also provides useful implications in the broader working capital management for managers in this sector which is consistent with the view that shorter CCC leads to higher profitability.

The findings also indicate that production cycle and debt ratio have a significant negative relationship with return on assets (ROA). It implies that efficient inventory management, production processes, and logistics management are crucial determinants to profitability especially in the agriculture and food industries. In addition, the results also suggest that higher leverage leads to lower profits for the agriculture and food industries in Thailand. The negative relationship between debt ratio and profitability may also help financial managers in this sector to be careful when making decisions for debt financing. Heavy debts can increase interest expenses and thus lower profits.

This study has also pointed out that payment cycle has a significant positive relationship with profitability. A related challenge in the agriculture and food industries is the limited credit period normally allowed by suppliers of perishable goods who may demand immediate payments for supplies provided. Though this may be true, the result of this study provides a challenging insight to managers to delay payments 
to suppliers to ensure higher profitability. The study did not find any significant relationship between cash collection cycle and profitability. Hence, it implies that receivables and cash collections do not significantly influence profitability in the agriculture and food industries in Thailand. The outcome further indicates that there was a significant positive relationship between size and profitability. From this, it can be concluded that cash conversion cycle has an impact on the financial performance of the agriculture and food industries in Thailand.

\subsection{Limitations and Recommendations}

The limitations of this study include the following. The sample size is quite small because of the limitation in accessing the companies' annual reports. There were a number of years that the companies did not post the annual reports on their official websites. Thus, it was quite difficult to extend the time frame for this study. In addition, some annual reports were only available in the Thai language which therefore hindered the interpretation of data for this study.

The study recommends that further research examines this relationship on other specific industries beyond the agriculture and food sector to see if they show similar results. Studies may also be conducted to observe the influence of cash conversion cycle on the profitability of all the manufacturing firms located in Thailand. Research can also be expanded to compare and contrast this relationship in the same industry with other ASEAN countries to gain further perspectives.

\section{References}

Afzal, M.N., Lawrey, R., Anaholy, M.S., \& Gope, J. (2018). A comparative analysis of the efficiency and productivity of selected food processing industries in Malaysia. Malaysian Journal of Sustainable Agriculture, 2(1), 1928. http://dx.doi.org/10.26480/mjsa.01.2018.19.28

Anser, R., \& Malik, Q.A. (2013). Cash conversion cycle and firms' profitability A study of listed manufacturing companies of Pakistan. Journal of Business and Management, 8(2), 83-87. http://dx.doi.org/10.9790/487X-0828387

Arunmas, P. (2017, June 1). Food exports forecast to grow 10.8\%. Bangkok Post. Retrieved from https://www.bangkokpost.com/business/news/ 1260114/food-exports-forecast-to-grow-10-8-

Attari, M.A., \& Raza, K. (2012). The optimal relationship of cash conversion cycle with firm size and profitability. International Journal of Academic Research in Business and Social Sciences, 2(4), 189-203. 
Besly, S.E., \& Brigham, E.F. (2000). Essentials of managerial finance. New York, NY: Dryden Press.

Bolek, M. (2013). Profitability as a liquidity and risk function basing on the new connect market in Poland. European Scientific Journal, 9(28), 1-15.

Brigham, E., \& Houston, J.F. (2013). Essentials of Financial Management (3rd edition). Singapore: Cengage Learning.

Chatterjee, S. (2012). The impact of working capital on the profitability: Evidence from the Indian firms. London: London School of Business and Finance.

Deloof, M. (2003). Does working capital management affect profitabilty of Belgian firms? Journal of Business Finance and Accounting, 30(3-4), 573-588. htpp:/ / dx.doi.org/10.1111/1468-5957.00008

Deutsche Gesellschaft für Internationale Zusammenarbeit (GIZ). (July 2011). Agriculture finance - Trends, issues and challenges. Retrieved from http:// www.ruralfinance.org/fileadmin/templates/rflc/documents/06_giz20110460en-agricultural-finance.pdf

Ebbens, J., \& Johnson, A. (2013). Cash conversion cycle management in small firms: Relationships with liquidity, invested capital, and firm performance. Journal of Small Businesss and Entrepreneurship, 24(3), 381-396. http:/ / dx.doi. org/10.1080/08276331.2011.10593545

Gentry, J.A., Vaidyanathan, L., \& Wai, H. (1990). A weighted cash conversion cycle. Financial Management, 19(1), 90-99. http://dx.doi.org/10.2307/ 3666040

Gibson, C.H. (2011). Financial reporting and analysis. Mason, OH: South Western Cengage Learning.

Gill, A., Nahum, B., \& Mathur, N. (2010). The relationship between working capital management and profitability: Evidence from the United States. Business and Economics Journal, 10(1), 1-9.

Gitman, I.S. (1982). A framework for estimating and analysing the required working capital investment. Review of Business and Economic Research, 17(3), 36-44.

Grosse-Ruyken, P.T., Wagner, S.M., \& Jonke, R. (2011). What is the right cash conversion cycle for your supply chain? International Journal of Services and Operations Management (IJSOM), 10(1), 13-29. http://dx.doi.org/10.1504/ IJSOM.2011.041987

Hassan, N.U., Imran, M.M., Amjad, M., \& Hussain, M. (2014). Effects of working capital management on firm performance: An empirical study of nonfinancial listed firms in Pakistan. International Journal of Academic Research in Business and Social Sciences, 4(6), 114-132. http://dx.doi.org/10.6007/ IJARBSS/v4-i6/931

Hemalatha, S., \& Kamalavalli, A.L. (2017). Impact of cash conversion cycle on profitability on tyre industry in India. International Journal of Multidisciplinary Research and Modern Education, 3(1), 139-142.

Hussain, S., \& Alnefaee, S. (2016). The effects of working capital management on profitability of firms: Evidence from agriculture and food industry of 
Kingdom of Saudia Arabia. Journal of Emerging Issues in Economics, Finance, and Banking, 5(1), 1684-1698.

Ikechukwu, O.I., \& Nwakaego, D.A. (2016). Cash conversion cycle management on the financial performance of building materials/chemical and paint manufacturing companies in Nigeria. Journal of Humanities and Social Science, 21(7), 62-69. http:/ / dx.doi.org/10.9790/0837-2107066269

Iqbal, A., \& Zhuquan, W. (2015). Working capital management and profitability evidence from firms listed on Karachi Stock Exchange. International Journal of Business and Management, 10(2), 231-235. http://dx.doi.org/10.5539/ ijbm.v10n2p231

Kaur, H.V., \& Singh, A. (2016). Relationship of cash conversion cycle with profitability: An analysis of power sector in India. International Journal of Emerging Issue in Management and Technology, 1(1), 32-45.

Kritchanchai, D. (2004). Assessing responsiveness of the food industry in Thailand. International Journal of Industrial Management and Data System, 104(5), 384-395. http:/ / dx.doi.org/10.1108/02635570410537471

Lyroudi, K., \& Larzridis, J. (July, 2000). The cash conversion cycle and liquidity analysis of the food industry in Greece. Paper presented at the European Financial Management Association Conference, Athens. Retrieved from https:/ / papers.ssrn.com/sol3/papers.cfm?abstract_id=236175

Majeed, S., Makki, M.A., Saleem, S., \& Aziz, T. (2013). The relationship of cash conversion cycle and profitability of firms: An empirical investigation of Pakistani firms. Journal of Emerging Issues in Economics, Finance and Banking (JEIEFB), 1(1), 35-51.

Makori, D.M., \& Jagongo, A. (2013). Working capital management and firm profitability: Empirical evidence from manufacturing and construction firms listed on Nairobi Securities. International Journal of Accounting and Taxation, 1(1), 1-14.

McClure, B. (2014, September 14). ROA and ROE give clear picture of corporate health. Retrieved from http://www.investopedia.com/articles/basics/05/ 052005.asp

Murugesu, T. (2013). Effect of cash conversion cycle on profitability: Listed plantation companies in Sri Lanka. Research Journal of Finance and Accounting, 4(18), 132-137.

Oseifuah, E.K., \& Gyekye, A. (2016). Cash conversion cycle theory and corporate profitability: Evidence from non-financial firms listed on the Johannesburg Stock Exchange. Journal of Accounting and Management, 6(9), 37-51. http:// dx.doi.org/10.21511/imfi.14(1).2017.08

Panigrahi, A.K. (2013). Cash conversion cycle and firm's profitability - A study of cement manufacturing companies of India. International Journal of Current Research, 5(6), 1484-1488.

Raheman, A., \& Nasr, M. (2007). Working capital management and profitability - case of Pakistani firms. International Review of Business Research Papers, 3(1), 279-300. 
Richards, D.V., \& Laughlin, J.E. (1980). A cash conversion cycle approach to liquidity analysis. Financial Management, 9(1), 32-38. http://dx.doi.org/ $10.2307 / 3665310$

Shah, S.Z., \& Chaudhry, S.N. (October, 2013). Relationship between cash conversion cycle and profitability: Moderator role of firm size. Paper presented at 2 nd International Conference on Management, Economics and Finance. Kota Kinabalu, Sabah, Malaysia.

Sharma, A.K. (2011). Effect of working capital management on firm profitability: Empirical evidence from India. Global Busines Review, 12(1), 159-173. http://dx.doi.org/10.1177/097215091001200110

Shin, H.H., \& Soenen, L. (1998). Efficiency of working capital management and corporate profitability. Financial Practice and Education, 8(2), 37-45.

Thailand Board of Investment. (2013). Thailand's food industry. Bangkok: Thailand Board of Investment.

Wongthatsanekorn, W. (October, 2010). Study of cash-to-cash cycle management on profitability of private hospital in Thailand by regular and panel data regression analyses. Paper presented at World Congress on Engineering and Computer Science, San Francisco, USA.

World Bank. (2016). Value added (\% of GDP): Agriculture. Retrieved from https:// data.worldbank.org/indicator/NV.AGR.TOTL.ZS?year_high_desc $=\mathrm{t}$

Yucel, T., \& Kurt, G. (2002). Cash conversion cycle, cash management and profitability: An empirical study on the ISE traded companies. The ISE Review, 6(22), 1-15. 
